\title{
Gonadal development in the freshwater crab Sylviocarcinus pictus (H. Milne Edwards, 1853) (Brachyura: Trichodactylidae) from the Guamá River, state of Pará, Brazil
}

\author{
LEILIANE S. SILVA ${ }^{1}$, JUSSARA M. MARTINELLI-LEMOS ${ }^{1}$, \\ MARIA AUXILIADORA P. FERREIRA ${ }^{2}$ and ROSSINEIDE M. ROCHA ${ }^{2}$ \\ ${ }^{1}$ Laboratório de Biologia Pesqueira e Manejo de Recursos Aquáticos, Instituto de Ciências Biológicas, \\ Universidade Federal do Pará (UFPA), Av. Perimetral, 2651, 66077-530 Belém, PA, Brasil \\ ${ }^{2}$ Laboratório de Ultraestrutura Celular, Instituto de Ciências Biológicas, \\ Universidade Federal do Pará (UFPA), Av. Augusto Corrêa, 01, 66075-100 Belém, PA, Brasil \\ Manuscript received on November 5, 2010; accepted for publication on May 2, 2011
}

\begin{abstract}
The development stages of male and female gonads in the freshwater crab Sylviocarcinus pictus (H. Milne Eduards, 1853) were described through macroscopic and microscopic (histology) examinations. The histological description was based on 40 specimens (20 each sex). Four gonadal development stages were found for females: immature, ripening, mature and spawned. The following female cells were found: ovogonia, oocytes in initial vitellogenesis, oocytes in advanced vitellogenesis, follicular cells and post-ovulatory follicles. Three development stages were found for males: immature, maturing and mature, with the indication of: spermatogonia, spermatocytes, spermatids, spermatozoids and spermatophores. These data suggest the pattern described in the literature. Size at sexual maturity was $32.3 \mathrm{~mm}$ of carapace width for males and $31.5 \mathrm{~mm}$ for females. The gonadal stages observed macroscopically by volume and color were validated through histological analysis and proved to be useful method for the rapid identification of sexual maturity in the species. The present study offers previously unpublished data on the reproductive biology of Sylviocarcinus pictus.
\end{abstract}

Key words: Amazon estuary, Gonadal histology, Reproduction.

\section{INTRODUCTION}

Sylviocarcinus pictus (H. Milne-Eduards, 1853) is a Trichodactylidae crab found in the northernnortheastern coastal river basins of South America, in the Amazon basin (Colombia, Peru, Bolivia and Brazil) (Magalhães 2003, Magalhães and Türkay 1996) and in the Paraná river basin (Collins et al.2009). The species is commonly found in rivers, creeks and lakes, occurring in different types of environments, such as dens in ravines, cracks or among the branches of submerged, roots, hollow tree trunks, or associated

Correspondence to: Jussara Moretto Martinelli-Lemos

E-mail: jussara@ufpa.br to aquatic macrophytes and under rocks (Magalhães 1999, 2000, Kowalczuk 2000 apud Magalhães 2003).

The gonads of freshwater crabs are located in the cephalothorax above the hepatopancreas. The male reproductive system consists of a pair of testes, a pair of vas deferens, two pairs of gonopods (modification of the first and second pair of pleopods) and a pair of penises (Cumberlidge 1999). The female reproductive system consists of a pair of ovaries, a pair of ovarian ducts and a pair of spermathecae, which terminate in two genital pores. After copulation the ovules develop, resulting in an increase of the ovary size and a 
change in color depending on the development stage and species (Chen et al. 1994, Cumberlidge 1999, Rostant et al. 2008).

Histological methods are commonly used on crustaceans to determine the phases of gonad growth and maturation (Chaves and Magalhães 1993, Pinheiro and Lins-Oliveira 2006, Castiglioni et al. 2007, Martins et al. 2007, Erkan et al. 2009, Silva et al. 2009), which can also be recognized by the outer appearance (Flores et al. 2002, Leme 2005, Barreto et al. 2006, Lima and Oshiro 2006).

However, there are few reports on the reproductive biology of freshwater crabs, examples of which include studies on the rate growth, reproduction period/ cycle, sex ratio and age structure of the freshwater crab Sinopotamon yangtsekiense Bott, 1967 (Chen et al. 1994), growth and maturity of Eudaniela garmani (Rathbun 1898) (Rostant et al. 2008) and a description of spermatozoon and spermatophore morphology in potamoid freshwater crabs, in which a close relationship between Deckeniinae and Gecarcinucidae could not be confirmed through spermatology (Klaus et al. 2009). Reproductive biology and growth of Trichodactylidae are limited to Dilocarcinus pagei Stimpson, 1861 (Mansur and Hebling 2002, Mansur et al. 2005, Pinheiro and Taddei 2005a, b) and Sylviocarcinus australis Magalhães and Türkay 1996 (Mansur and Hebling 2002, Mansur et al. 2005).

Studies on $S$. pictus are restricted to taxonomic and distributinal aspects. In the state of Pará (northern Brazil) there are records of the occurrence of only eight species of Trichodactylidae (Barros and Pimentel 2001) and there are no previous data on the histological description of the gonads of the genus Sylviocarcinus. The aim of the present study was to describe the development stages of male and female gonads in Sylviocarcinus pictus.

\section{MATERIALS AND METHODS}

The specimens were sampled from the Combu Island Environmental Protection Area, Guamá River, Guajará Bay, state of Pará (northern Brazil) $\left(01^{\circ} 30^{\prime} \mathrm{S}\right.$ and $\left.48^{\circ} 27^{\prime} \mathrm{W}\right)$. The Combu Island Environmental Protection Area has an area of $15 \mathrm{~km}^{2}$ and is the fourth largest island within the limits of the municipality of Belém (Pará). The island has small, very narrow tidal channels spanning few meters and is characterized by a large amount of vegetal formations throughout its entire extension, which culminate in the formation of very large shaded areas similar to swamps (Bentes et al. 2011). The climate of the region is AM (Köppen classification), with a mean annual temperature of $27{ }^{\circ} \mathrm{C}$ (Jardim and Vieira 2001). The annual rainfall in the region ranges from 2300 to $2800 \mathrm{~mm}$ and the rainy season occurs from December to June (Moraes et al. 2005).

Sampling was carried out in August 2006, which is the month with the greatest representativity of the population, in which juveniles and adults in all phases of gonadal development were found (Silva 2010). The crabs were collected with traps, known locally as 'matapi', made from palm splints, with a cylindrical shape and the ends turning inward to forming a funnel $-82.5 \mathrm{~cm}$ in length and $28 \mathrm{~cm}$ in diameter, with three diameter sizes for the openings $(5.5 / 8.0 / 10.0 \mathrm{~cm})$. The traps were baited with the catfish Hoplosternum spp. (Siluriformes: Callichthyiae). Each sample unit contained one fish cut in the middle in the dorsal-ventral direction tied with a string so that the bait remained suspended in the center of the trap.

Following the capture, the specimens were anesthetized by cooling for 30 minutes. Carapace width $(\mathrm{CW})$ was measured with calipers with a precision of $0.01 \mathrm{~mm}$. The dorsal portion of the carapace was removed for the exposure of the reproductive organs, which were examined and removed from the thoracic cavity.

The gonadal development stages for both sexes of $S$. pictus were investigated using two methods: macroscopic examination of the consistence, volume and coloration of the reproductive system in relation to the hepatopancreas and thoracic cavity (adapted from Mota-Alves 1975, 
Mantelatto and Fransozo 1999) and microscopic examination of cells types (Chaves and Magalhães 1993, Castilho et al. 2008, Keunecke et al. 2009).

For the histological description, 20 gonads of each sex were randomly selected from specimens collected in August 2009, ranging in CW from 27.86 to 43.90 (average of $35.84 \pm 4.24 \mathrm{~mm}$ of standard deviation), encompassing both juveniles and adults. The gonads were fixed in Bouin's solution for 24 hours, stored in $70 \%$ alcohol and subsequently dehydrated in increasing concentrations of alcohol ( $70 \%$ to $100 \%)$, diaphanized in xylol, infiltrated and embedded in paraffin. Sections of $5 \mu \mathrm{m}$ were cut on a microtome (Leica 2245). Slides with the histological cuts were stained with hematoxylineosin (H.E.), analyzed with an optical microscope (Zeiss Axiostar Plus) and photomicrographed (Canon Power Shot 12.1 Megapixels).

\section{RESULTS}

FEMALES

Macroscopically, the differences in ovarian stages varied in accordance with shape, coloration and location. In immature females, the ovaries were located ventrally to the stomach between the mid and anterior regions of the thoracic cavity. In mature females, the ovaries occupied the lower portion of the thoracic cavity between the cardiac region and the insertion base of the fifth pereiopod (Fig. 1). The macroscopic and microscopic examination of the ovaries allowed the identification of four gonadal stages:

Stage I (immature or pre-vitellogenic): The ovaries were difficult to view, bear a filiform shape and transparent appearence, with no oocytes visible to the naked eye (Fig. 1a). Rounded ovogonia were found, with little affinity for stains and evenly distributed in the tissue. Follicular cells were also observed, organized in a cordlike manner and smaller in size in relation to the ovogonia (Fig. 2a).

Stage II (ripening or in vitellogenesis): The ovaries had a larger volume, with the coloration ranging from white to yellowish. Some oocytes could be seen with the naked eye (Fig. 1c). Oocytes were found in both initial and advanced vitellogenesis. These cells were surrounded by follicular cells with a flat aspect (Fig. 2b).

Stage III (mature or complete vitellogensis): The ovaries had an orange coloration, cylindrical shape and increased size, occupying one quarter $(1 / 4)$ of the thoracic cavity. Oocytes visible to the naked eye were frequent (Fig. 1e). There was a predominance of mature oocytes enveloped in conjunctive tissue and few follicular cells (Fig. 2c).

Stage IV (spawned): The ovaries had a pale yellow coloration and a flaccid appearance, occupying a larger space in the body cavity in comparison to Stage II (Fig. 1g). Post-ovulatory follicles, atresic oocytes and some mature oocytes were observed (Fig. 2d).

\section{MALES}

The testes exhibited varied coloration and consistency and were made up of various seminiferous tubules, with each tubule enveloped in conjunctive tissue (Fig. 3a). The macroscopic and microscopic examinations allowed the classification of the testes in three stages:

Stage I (immature): The testes and vasa deferentia had a transparent coloration and gelatinous aspect, occupying little volume in the thoracic cavity (Fig. 1b). Spermatogonia and spermatocytes occupying the lumen of the seminiferous tubules were identified microscopically (Fig. 3b).

Stage II (maturing): The testes and vasa deferentia had a whitish coloration and gelatinous aspect with an increase in size and volume in relation to the previous stage (Fig. 1d). The testes exhibited spermatocytes and spermatids undergoing cell division in nearly the entire lumen as well as few spermatozoids (Fig. 3c).

Stage III (mature): The testes had a whitish coloration with a milky aspect and the vasa deferentia were either yellowish or brown. Both were large in volume, occupying nearly the entire thoracic cavity 

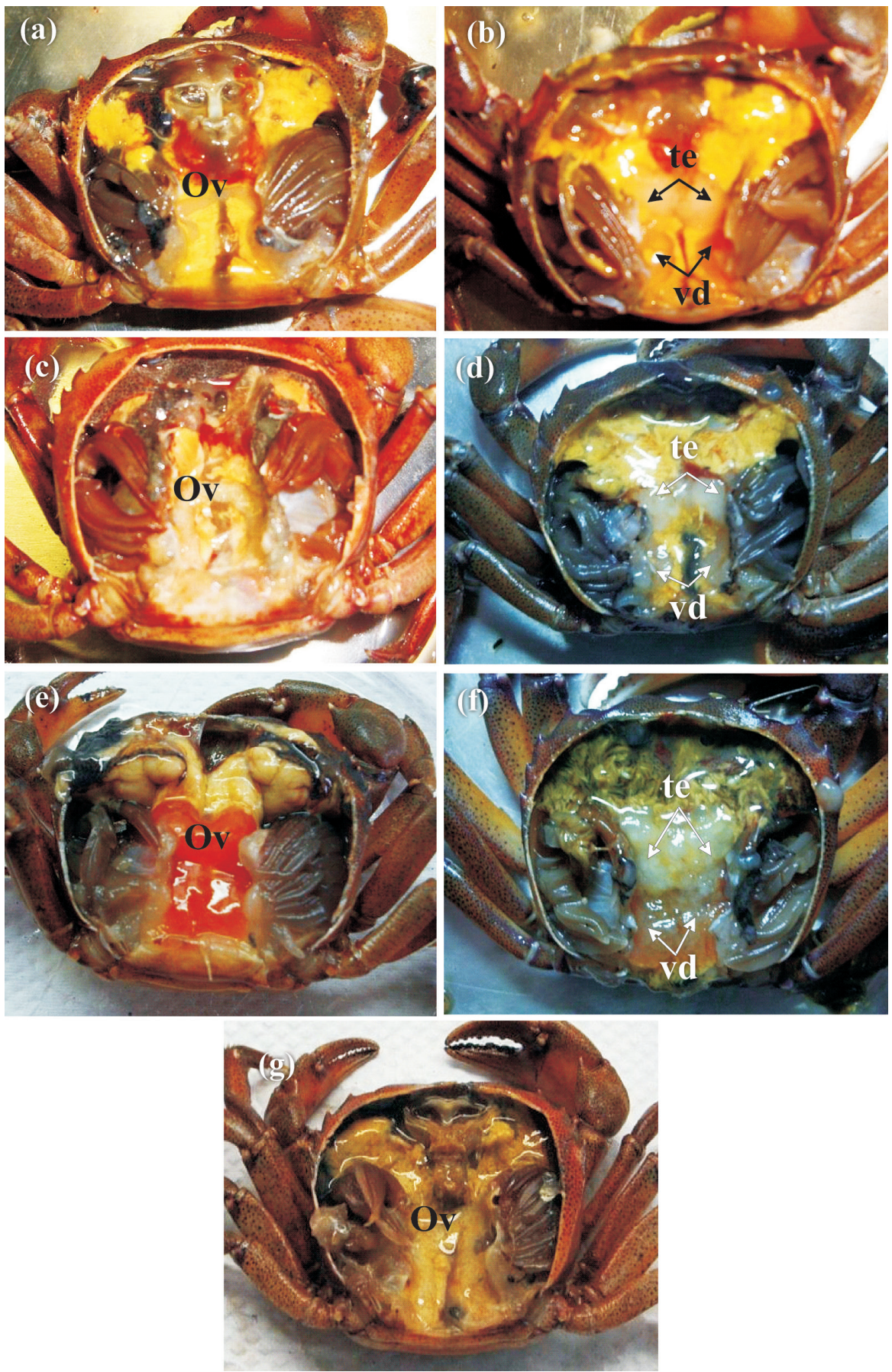

Fig. 1 - Dorsal view of a female (left column) and a male (right column) of Sylviocarcinus pictus showing changes in size and color of the reproductive organs at different stages of the reproductive cycle. Immature stage: a- ovaries (ov) had a filiform shape and transparent color, b- testes (te) and vasa deferentia (vd) had a transparent coloration and gelatinous aspect; Ripening/ Maturing stage: $\mathbf{c}$ - ovaries had a larger volume, with the coloration ranging from white to yellowish, $\mathbf{d}$ - testes and vasa deferentia had a whitish coloration and gelatinous aspect; Mature stage: e- ovaries showing an increase in size and an orange coloration, $\mathbf{f}$ testes and vasa deferentia with an increase in size and volume; Spawned stage: g- ovaries had a flaccid appearance and a pale yellow coloration. 

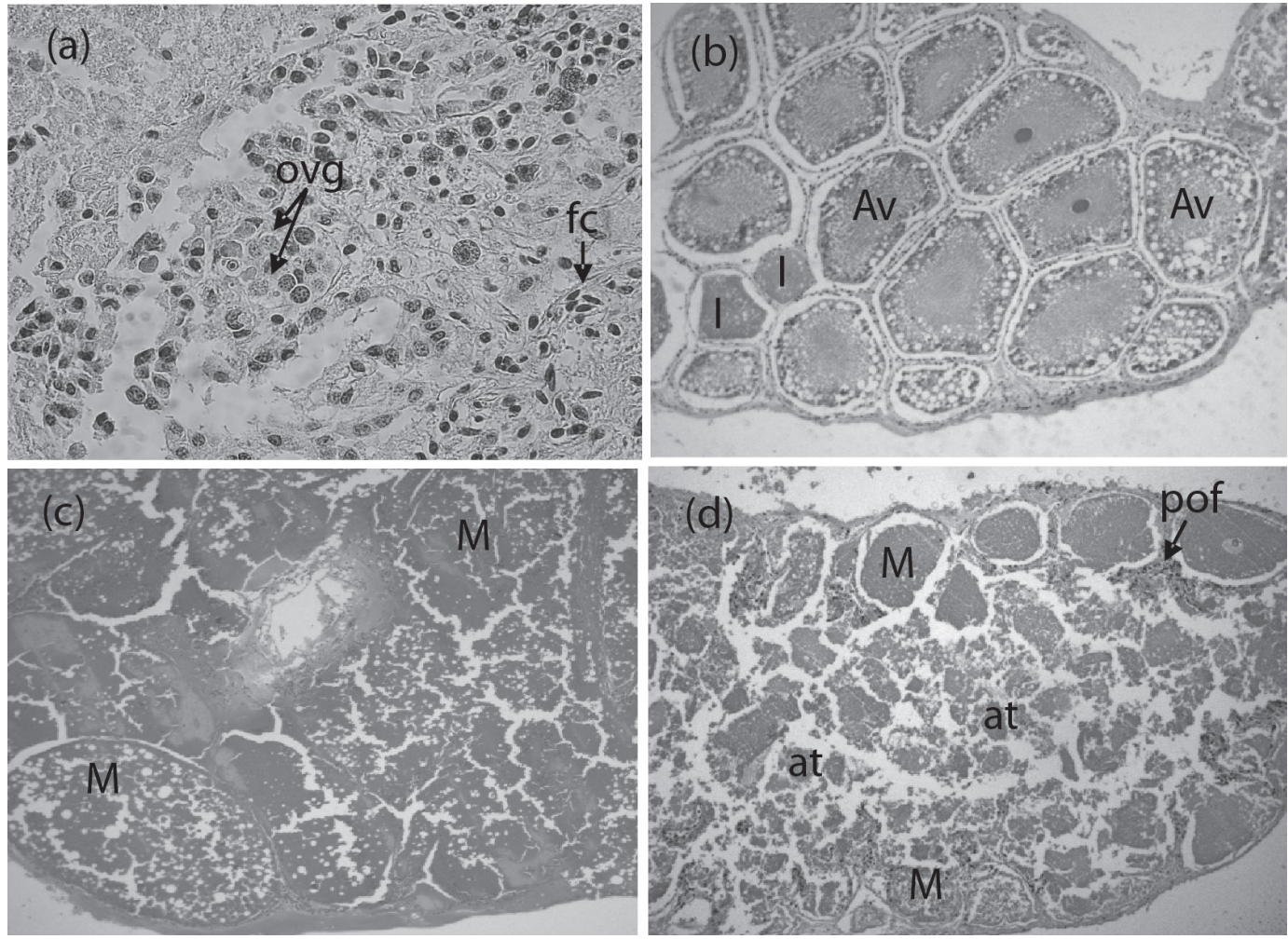

Fig. 2 - Ovary of the crab Sylviocarcinus pictus: a- immature stage: presence of ovogonia (ovg), follicular cells (fc), 400x; b- ripening stage: presence of oocytes in initial vitellogenesis (I) and advanced vitellogenesis (Av), 200x; c- mature stage: presence of mature oocytes (M), 100x; d- spawned stage: presence of post-ovulatory follicles (pof), mature oocytes (M) and atresic oocytes (at), 200x.

(Fig. 1f). In the testes, spermatozoids were found in all the seminiferous tubules (Fig. 3d).

The vas deferens in $S$. pictus was divided into three regions: proximal, medial and distal. In general, the vasa deferentia have a cylindrical shape coated by support cells delimiting the lumen and filled by colloid and spermatozoids or spermatophores, depending on the reproductive phase. The spermatophores were spherical and consisted of various spermatozoids enveloped by a thin membrane (Fig. 3g).

The proximal vas deferens had a tall cylindrical cellular epithelium, with the lumen filled by colloid or loose spermatozoids (Fig. 3e) in individuals in Stages II and III. The medial vas deferens also had a cylindrical cellular epithelium, with the lumen filled by colloid and spermatophores of different sizes (Fig. 3f). The distal vas deferens had larger dimensions than the medial vas deferens and was made up of a basal cellular epithelium, with the lumen filled by colloid and spermatophores; the amount of spermatophores was greater in mature individuals. No spermatophores were found in the medial or distal vas deferens in immature or maturing individuals.

Carapace width of the specimens ranged from 27.8 to $43.9 \mathrm{~mm}(\mathrm{~N}=40$; mean \pm standard deviation: $35.84 \pm 4.24 \mathrm{~mm})$. The size at sexual maturity found was $32.3 \mathrm{~mm} \mathrm{CW}$ for males and $31.5 \mathrm{~mm}$ for females. Table I displays the size data for each sex in different developmental stages.

\section{DISCUSSION}

The male reproductive system in Sylviocarcinus pictus is made up of a pair of testes, a pair of vasa deferentia, two pairs of gonopods and a pair of 

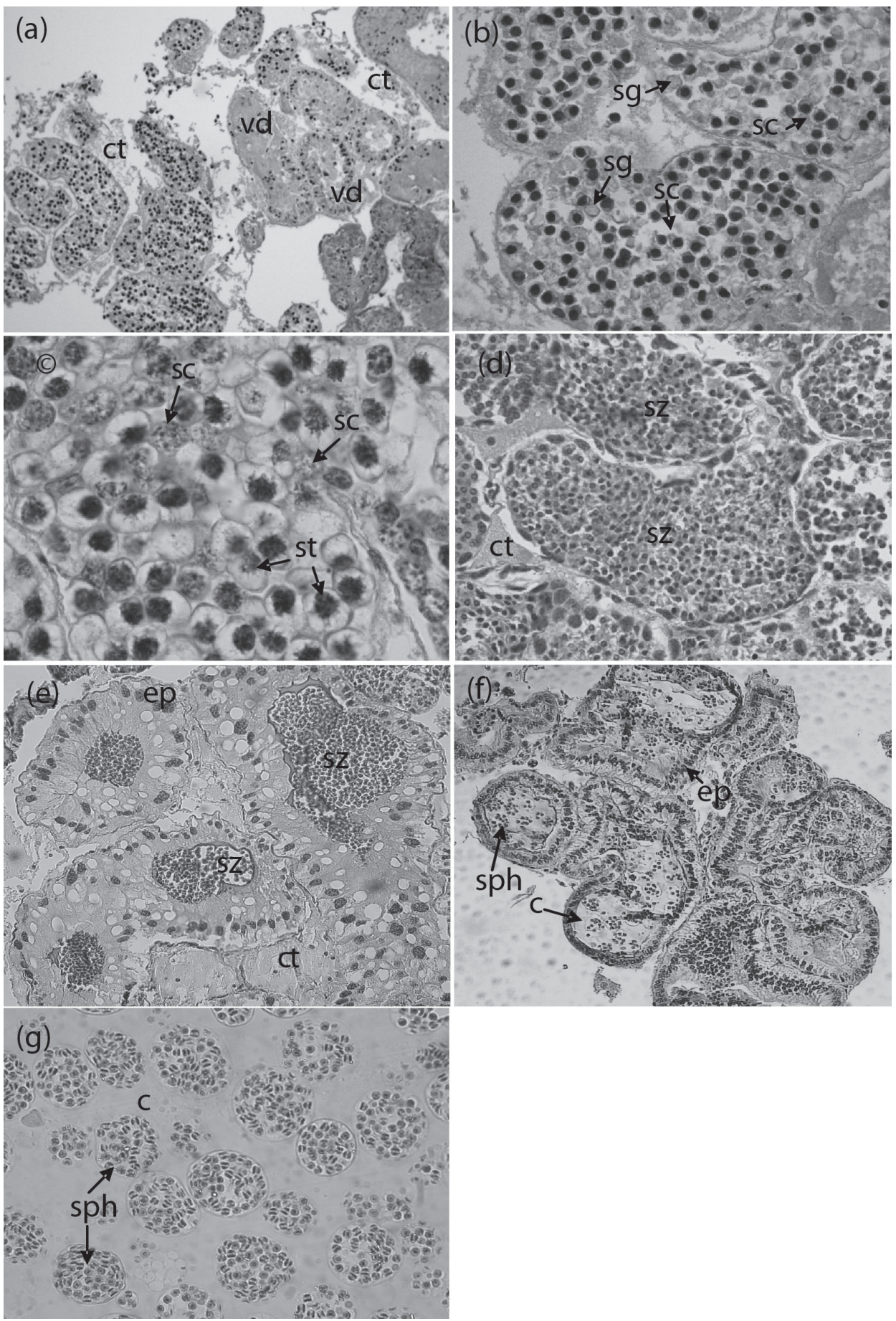

Fig. 3 - Testicle of the crab Sylviocarcinus pictus: a- Cross section of seminiferous tubules $(\mathrm{t})$ and vas deferens (vd) enveloped in conjunctive tissue (ct), 100x; b- immature stage: presence of spermatogonia (sg) and spermatocytes (sc), 400x; c- maturing stage: presence of spermatocytes and spermatids (st) in cell division, 1000x; d- mature stage: cross section of a seminiferous tubule with the presence of spermatozoids (sz), 400x; e- cross section of proximal vas deferens: presence of spermatozoids enveloped in cylindrical cellular epithelium (ep), 200x; f- cross section of medial vas deferens: presence of colloid (c) and spermatophores (sph) enveloped in cylindrical cellular epithelium, 100x; g- spermatophores, 400x. 
TABLE I

Variation in size (carapace width, in $\mathrm{mm}$ ) of females $(\mathrm{N}=20)$ and males $(\mathrm{N}=20)$ specimens of Sylviocarcinus pictus that were found in different gonadal development stages.

\begin{tabular}{c|c|c}
\hline \multirow{2}{*}{$\begin{array}{c}\text { Development } \\
\text { Stages }\end{array}$} & $\begin{array}{c}\text { Females } \\
\text { (minimum- } \\
\text { maximum) }\end{array}$ & $\begin{array}{c}\text { Males (minimum- } \\
\text { maximum) }\end{array}$ \\
\cline { 2 - 3 } & $27.8-30.9$ & $30.2-30.6$ \\
Immature & $29.8-39.7$ & $30.5-34.2$ \\
Maturing & $31.5-40.7$ & $32.3-43.7$ \\
Mature & $32.6-43.9$ & -- \\
Spawned & \multicolumn{2}{|c}{} \\
\hline
\end{tabular}

penises. The female reproductive system is made up of a pair of ovaries, a pair of ovarian ducts, a pair of spermathecae and a pair of genital openings. The morphology of the gonads in S. pictus follows the pattern described for other brachyurans (Chen et al. 1994, Leme 2005, Castilho et al. 2008, Rostant et al. 2008, Keunecke et al. 2009, Souza and Silva 2009). The typical H shape was only observed in the male gonads, whereas the female gonads had a shape resembling an inverted $\mathrm{U}$.

Regarding size, immature females were found with up to $30.9 \mathrm{~mm} \mathrm{CW}$. However, some individuals larger than $29.8 \mathrm{~mm}$ had ovaries in Stage II of gonad development (ripening). The smallest mature female was $31.5 \mathrm{~mm}$, indicating that females are found physiologically capable of reproduction from this size on. Females larger than $32.6 \mathrm{~mm}$ were found with the ovaries in Stage IV (spawned), which indicates that the fecundation of mature oocytes had occurred and those that were not fertilized were being resorbed. These findings are in agreement with the size at sexual maturity estimated by Silva (2010). For males, individuals with a $\mathrm{CW}$ beginning at 32.3 $\mathrm{mm}$ are physiologically ready for reproduction. At this size, the testes and vasa deferentia are replete with spermatozoids/spermatophores.

The histological analysis of the ovaries revealed a gradual process of oocyte development based on cellular characteristics, in which ovogonia, oocytes in initial vitellogenesis, oocytes in advanced vitellogenesis, mature oocytes, follicular cells and post-ovulatory follicles were observed. With the exception of the post-ovulatory follicles, these cell types have also been found in other species of crabs (Castiglioni et al. 2007, Rostant et al. 2008, Santos et al. 2009, Souza and Silva 2009).

Post-ovulatory follicles are reported for the prawn Macrobrachium amazonicum and the swimming crabs Callinectes danae and Callinectes ornatus (Chaves and Magalhães 1993, Keunecke et al. 2009). Post-ovulatory follicles indicate recent spawning (Rjeibi et al. 2010) and this is the first time such follicles are reported for freshwater crabs. The follicular cells were present in all stages of development in S. pictus, being more frequently on stages I and IV. According to Shinozaki-Mendes et al. (2011b), follicular cells are responsible for synchronic maturation, thereby ensuring the necessary amount of mature oocytes for spawning.

During the maturation process, there are histological and morphological alterations. The gonads change in volume and are easily seen by macroscopic examination. The coloration of the ovaries in S. pictus ranged from transparent when immature to white and yellow tones in stages II and IV. The sequence in the change of color was similar to that described for the freshwater crabs Eudaniela garmani and Sinapotamon yangtsekiense, in which transparent ovaries change to a white color until acquiring a cream color, followed by yellow and ending up bright orange, evidenced by the accumulation of yolk (Rostant et al. 2008, Chen et al. 1994, respectively).

The development of the male gonads in $S$. pictus was divided into three stages. However, maturation stages may vary depending on the species and method used. For Ucides cordatus and Cardisoma guanhumi, only two development stages are generally used (immature and mature), based on the presence or absence of spermatophores in the distal vas deferens and ejaculatory ducts 
(Dalabona and Silva 2005, Castilho et al. 2008). This division with few stages is sufficient when it comes to species management.

The coloration and cell types followed the pattern described in the literature for other decapod species (Noro et al. 2007, Castilho et al. 2008, Erkan et al. 2009, Santos et al. 2009, ShinozakiMendes et al. in press). The cell types found in the male reproductive system were spermatogonia, spermatocytes, spermatids, spermatozoids and spermatophores, which modified the coloration of the gonads throughout the maturation process, ranging from transparent in immature individuals to white in mature individuals.

The vas deferens in $S$. pictus were divided into three distinct regions, as reported for other decapods (Noro et al. 2007, Amadio and Mantelatto 2009, Erkan et al. 2009, Santos et al. 2009). In the proximal vas deferens, a cylindrical epithelium was found, with loose spermatozoids in the lumen and an absence of spermatophores, which is similar to what was described for Armases rubrises, Ucides cordatus and Cardisoma guanhumi (Castilho et al. 2008, Santos et al. 2009, Shinozaki-Mendes et al. in press). The spermatophores were found in the medial and distal vas deferens. The medial vas deferens was smaller and had fewer spermatophores in relation to the distal vas deferens. A spermatophore is a capsule formed by an acellular wall (Moriyasu and Benhalima 1998). In S. pictus, spermatophores exhibited a spherical shape, which is the most common spermatophore shape among brachyurans that have internal fecundation, with the storage of spermatophores directly in the spermathecae of the females (Erkan et al. 2009).

Brachyuran spermatozoids are generally cells with uncondensed chromatin, a wide acrosome and variable number of radial arms, depending on the species (Medina and Rodríguez 1992, Klaus et al. 2009). The method employed in the present study did not allow the acquisition of detailed characteristics of the spermatozoids.
The analysis of the gonadal stages in S. pictus through macroscopic examination and histology demonstrated no differences in the stages between the two approaches, as previously described for the family Portunidae (Mantelatto and Fransozo 1999), for example.

\section{ACKNOWLEDGMENTS}

The authors are grateful to $\mathrm{PhD}$. Célio Magalhães for kindly confirming the species of Trichodactylidae; to fishery engineer Douglas Bastos, biologist Alyne Araújo Gama and their parents; to $\mathrm{Mr}$. João Rosa and his wife for the logistical support in the acquisition of the samples. The support of the Brazilian fostering agency Coordenação de Aperfeiçoamento de Pessoal de Nível Superior (CAPES) for the Master's scholarship granted to the first author and native speaker Richard Boike for the translation into the English language is gratefully acknowledged. This study complies with current applicable state and federal laws of Brazil (IBAMA/MMA n02018.00729/06-36). The authors are indebted to the anonymous referees for improving the manuscript.

\section{RESUMO}

Os estádios de desenvolvimento das gônadas de machos e fêmeas de caranguejos Sylviocarcinus pictus $(\mathrm{H}$. Milne Eduards, 1853) foram descritos por meio de observações macroscópicas e microscópicas (técnica histológica). A descrição histológica foi baseada em 40 espécimes (20 de cada sexo). Foram identificados quatro estádios de desenvolvimento para as fêmeas: imaturo, em maturação, maturo e em reabsorção. As seguintes células foram encontradas: ovogônias, ovócitos em vitelogênese inicial, ovócitos em vitelogênese avançada, células foliculares e folículos pós-ovulatórios. Três estádios de desenvolvimento foram encontrados para os machos: imaturo, em maturação e maturo, com indicação de: espermatogônias, espermatócitos, espermátides, espermatozóides e espermatóforos. Tais dados sugerem o 
padrão descrito na literatura. O tamanho da maturidade sexual foi de 32,3 $\mathrm{mm}$ de largura da carapaça para machos e 31,5 mm para fêmeas. Os estádios gonadais observados macroscopicamente por meio do volume e da coloração das gônadas foram validados pela análise histológica, sendo um critério útil e ágil para a identificação da maturidade sexual para a espécie. O presente estudo oferece informações inéditas sobre a biologia reprodutiva de Sylviocarcinus pictus.

Palavras-chave: estuário Amazônico, histologia gonadal, reprodução.

\section{REFERENCES}

Amadio ML and Mantelatto FL. 2009. Description of the male reproductive system of the hermit crab Calcinus tibicen (Decapoda: Anomura: Diogenidae). J Crust Biol 29: 466-475.

BArReto AV, BAtistA-Leite LMA AND AgUiAr MCA. 2006. Maturidade sexual das fêmeas de Callinectes danae (Crustacea, Decapoda, Portunidae) nos estuários dos Rios Botafogo e Carrapicho, Itamaracá, PE, Brasil. Iheringia Ser Zool 96: 141-146.

Barros MP AND Pimentel FR. 2001. A Fauna de Decapoda (Crustacea) do Estado do Pará, Brasil: Lista preliminar das espécies. Bol Mus Para Emilio Goeldi 17: 15-41.

Bentes B, Martinelli JM, Silva LS, Cavalcante DV, ALMEIDA MC AND ISAAC VJ. 2011. Spatial distribution of the Amazon River Shrimp Macrobrachium amazonicum (Heller, 1862) (Decapoda, Caridea, Palaemonidae) in two perennial creeks of an estuary on the northern coast of Brazil (Guajará Bay, Belém, Pará). Braz J Biol 71: 925-935.

CAstiglioni DS, Negreiros-Fransozo ML, Greco LSL, SILVEIRA AF AND SILVEIRA SO. 2007. Gonad development in females of fiddler crab Uca rapax (Crustacea: Brachyura: Ocypodidae) using macro and microscopic techniques. Iheringia Ser Zool 97: 505-510.

CAstilho CG, Ostrensky A, Pie MR And Boeger WA. 2008. Morphology and histology of the male reproductive system of the mangrove land crab Ucides cordatus (L.) (Crustacea, Brachyura, Ocypodidae). Acta Zool 89: 157-161.

Chaves PTC AND MagalHães C. 1993. O desenvolvimento ovocitário em Macrobrachium amazonicum (Heller, 1862) (Crustacea: Decapoda: Palaemonidae) camarão dulcícola da região Amazônica. Acta Amaz 23: 17-23.

CHEN T, LAI W AND DU N. 1994. Growth, reproduction \& population structure of the freshwater crab Sinopotamon yangtsekiense Bott, 1967, from Zhejiang, China. Chin J Oceanol Limnol 12: 84-90.

COLLINS PA, GIRI F AND WiLLINER V. 2009. Range extension for three species of South American freshwater crabs (Crustacea: Decapoda: Trichodactylidae). Zootaxa 1977: 49-54.
Cumberlidge N. 1999. The freshwater crabs of West Africa. Family: Potamonautidae. France: Institute de Recherche pour le Development, $382 \mathrm{p}$.

Dalabona G and Silva JL. 2005. Período reprodutivo de Ucides cordatus (Linnaeus) (Brachyura, Ocypodidae) na Baía das Laranjeiras, Sul do Brasil. Acta Biol Par 34: 115-126.

ERKan M, Tunali Y, Balkis H AND Oliveria E. 2009. Morphology of testis and vas deferens in the xanthoid crab, Eriphia verrucosa (Forskal, 1775) (Decapoda: Brachyura). J Crust Biol 29: 458-465.

Flores AAV, SARAiva J AND PAUla J. 2002. Sexual maturity, reproductive cycles, and juvenile recruitment of Perisesarma guttatum (Brachyura, Sesarmidae) at Ponta Rasa mangrove swamp, Inhaca Island, Mozambique. J Crust Biol 22: 143-156.

JARDIM MAG AND VIEIRA ICG. 2001. Composição florística e estrutura de uma floresta de várzea do estuário Amazônico, Ilha do Combu, Estado do Pará. Bol Mus Para Emilio Goeldi 17: 333-354.

Keunecke KA, Silva JR DR, Vianna M, Verani JR AND D'INCAO F. 2009. Ovarian development stages of Callinectes danae and Callinectes ornatus (Brachyura, Portunidae). Crustaceana 82: 753-761.

KLAUS S, SCHUBART CD AND BRANDIS D. 2009. Ultrastructure of spermatozoa and spermatophores of Old World freshwater crabs (Brachyura: Potamoidea: Gecarcinucidae, Potamidae, and Potamonautidae). J Morphol 270: 175-193.

LEME MHA. 2005. Size and sexual maturity of female crabs Sesarma rectum Randall (Crustacea, Brachyura) and ontogenetic variations in the abdomen relative growth. Rev Bras Zool 22: 433-437.

Lima GV AND OshiRo LMY. 2006. Maturidade sexual do caranguejo Armases rubripes (Rathbun) (Crustacea, Brachyura, Sesarmidae) na Baía de Sepetiba, Rio de Janeiro, Brasil. Rev Bras Zool 23: 1078-1086.

Magalhães C. 2003. Famílias Pseudothelphusidae e Trichodactylidae. In: MELO GAS (Ed), Manual de identificação dos Crustacea Decapoda de água doce do Brasil, São Paulo: Edições Loyola, p. 143-287.

MAgalHãES C AND TÜRKAY M. 1996. Taxonomy of the neotropical freshwater crab family Trichodactylidae. II. The Genera Forsteria, Melocarcinus, Sylviocarcinus and Zilchiopsis (Crustacea: Decapoda: Brachyura). Senckenberg Biol 75: 97-130.

MANSUR CB AND HEBLING NJ. 2002. Análise comparativa entre a fecundidade de Dilocarcinus pagei Stimpson e Sylviocarcinus australis Magalhães e Türkay (Crustacea, Decapoda, Trichodactylidae) no Pantanal do rio Paraguai, Porto Murtinho, Mato Grosso do Sul. Rev Bras Zool 19: 797-805.

Mansur CB, Hebling NJ and Souza JA. 2005. Crescimento relativo de Dilocarcinus pagei Stimpson, 1861 e Sylviocarcinus australis Magalhães e Türkay, 1996(Decapoda: Trichodactylidae) no pantanal do rio Paraguai, Porto Murtinho - Mato Grosso do Sul. Bol Inst Pesca 31: 103-107.

Mantelatto FLM AND Fransozo A. 1999. Reproductive biology and moulting cycle of the crab Callinectes ornatus (Decapoda, Portunidae) from the Ubatuba region, São Paulo, Brazil. Crustaceana 72: 63-76. 
MARTINS J, RIBEIRO K, RANGEL-FIGUEIREDO T AND COIMBRA J. 2007. Reproductive cycle, ovarian development, and vertebrate-type steroids profile in the freshwater prawn Macrobrachium rosenbergii. J Crust Biol 27: 220-228.

MEdinA A AND RodRíGUEZ A. 1992. Spermiogenesis and sperm structure in the crab Uca tangeri (Crustacea, Brachyura), with special reference to the acrosome differentiation. Zoomorphology 111: 161-165.

Moraes BC, Costa JMN, Costa CL And Costa MH. 2005. Variação espacial e temporal da precipitação no estado do Pará. Acta Amaz 35: 207-214.

Moriyasu M AND Benhalima K. 1998. Snow crabs, Chionoecetes opilio (O. Fabricius, 1788) (Crustacea: Majidae) have two types of spermatophore: hypotheses on the mechanism of fertilization and population reproductive dynamics in the southern Gulf of St. Lawrence, Canada. J Nat Hist 32: 1651-1665.

MotA-ALVES MI. 1975. Sobre a reprodução do caranguejo-uçá, Ucides cordatus (Linnaeus), em mangues do Estado do Ceará (Brasil). Arq Cienc Mar 15: 85-91.

Noro CK, Silva-Castiglioni D, López-Greco L, Buckup L AND BOND-BUCKUP G. 2007. Morphology of the vasa deferentia of Parastacus defossus and P. varicosus and comparison within the Parastacidae. Nauplius 15: 43-48.

PINHEIRO AP AND LINS-OLIVEIRA JE. 2006. Reproductive biology of Panulirus echinatus (Crustacea: Palinuridae) from São Pedro and São Paulo Archipelago, Brazil. Nauplius 14: 89-97.

PINHEIRO MAA AND TADDEI FG. 2005a. Crescimento do caranguejo de água doce, Dilocarcinus pagei Stimpson (Crustacea, Brachyura, Trichodactylidae). Rev Bras Zool 22: 522-528.

PINHEIRO MAA AND TADDEI FG. 2005b. Relação peso/largura da carapaça e fator de condição em Dilocarcinus pagei Stimpson (Crustacea, Trichodactylidae), em São José do Rio Preto, São Paulo, Brasil. Rev Bras Zool 22: 825-829.

RJeibi O, GaAmour A AND Missaoui H. 2010. Kinetics of oogenesis and spawning strategy of the red spiny lobster Palinurus elephas. J Crust Biol 30: 401-412.
Rostant LV, Alkins-Koo M And Maitland DP. 2008 Growth and maturity in the manicou crab Eudaniela garmani (Brachyura: Pseudothelphusidae) from Trinidad, Westindies. J Crust Biol 28: 485-493.

SANTOS CM, Lima GV, NASCimento AA, SALES A AND OSHIRO LMY. 2009. Histological and histochemical analysis of the gonadal development of males and females of Armases rubripes (Rathbun 1897) (Crustacea, Brachyura, Sesarmidae). Braz J Biol 69: 161-169.

SHINOZAKI-MENDES RA, SILVA JRF AND HAZIN FHV. In press. Development of male reproductive system of the blue land crab Cardisoma guanhumi Latreille, 1828 (Decapoda: Gecarcinidae). Acta Zool. Doi: 10.1111/ j.1463-6395.2011.00513

ShINOZAKI-MENDES RA, Silva JRF, Souza LP AND HazIN FHV. 2011b. Histochemical study of the ovarian development of the blue land crab (Crustacea: Gecarcinidae). Invertebrate Reproduction \& Development, p. 1-9. iFirst. Doi: 10.1080/07924259.2011.587277.

SILVA GMF, FERREIRA MAP, LEDEBUR EICFV AND ROCHA RM. 2009. Gonadal structure analysis of Macrobrachium amazonicum (Heller, 1862) from a wild population: a new insight into the morphotype characterization. Aquac Res 40: 798-803.

SILVA LS. 2010. Estrutura populacional e maturidade sexual de Sylviocarcinus pictus (H. Milne-Eduards, 1853) e $S$. devillei H. Milne-Eduards, 1853 (Brachyura, Trichodactylidae) das ilhas do estuário amazônico no entorno de Belém, Pará, Brasil. Dissertação de mestrado, Ecologia Aquática e Pesca. Universidade Federal do Pará, Pará, 103 p. Available at http://www3.ufpa.br/ppgeap/ images/stories/PPGEAP_Dissertacao_Leiliane_Souza_ Silva_juno2010.pdf. (Unpublished).

SouZA LP AND SILVA JRF. 2009. Morphology of the female reproductive system of the red-clawed mangrove tree crab (Goniopsis cruentata Latreille, 1803). Sci Mar 73: 527-539. 